\title{
Deregulated Expression of Cell Cycle-Associated Proteins in Solid Pseudopapillary Tumor of the Pancreas
}

\author{
J. Müller-Höcker, M.D., Ph.D, Ch. Zietz, M.D., A. Sendelhofert \\ Institute of Pathology, University of Munich, Munich, Germany
}

Solid pseudopapillary tumor of the pancreas was studied in a 20-year-old woman and a 54-year-old woman. In the younger patient, the tumor had metastasized to the liver 8 years after distal pancreatectomy. In both neoplasms, the distinct histologic pattern of solid, pseudopapillary, and degenerative cystic areas was present. Analysis by means of immunohistochemistry revealed a diffuse expression for vimentin, neuron-specific enolase, and a focal positivity for $\alpha 1$-antitrypsin, whereas epithelial markers were negative in the tumor of the older patient and only focally expressed in the tumor of the younger patient. Immunohistochemical analysis of cell cycle-associated proteins provided an overexpression of cyclin D1 and cyclin D3 in both tumors, although to varying degrees. In addition, the cyclin-dependent kinase inhibitors p21, and to a lesser extent p27, were up-regulated just as $\mathbf{m d m} 2$. There was no accumulation of p53 protein, and Ki67-positive cells were extremely scarce. Analysis of the liver metastases showed an immunoreactive profile similar to that of the primary tumor. The results show a deregulation of the cell cycle with overexpression of cell cycle-activating proteins D1 and D3 and a probably counterbalancing upregulation of the cyclin-dependent kinase inhibitors p21 and p27. The findings may explain the low pool of Ki67-reactive tumor cells and the generally good clinical outcome of these tumors. Whether a more profound dysbalance of the cell cycle regulation is responsible for the development of metastatic disease remains to be clarified.

KEY WORDS: Cell cycle proteins, Immunohistochemistry, Pancreas, Solid pseudopapillary tumor.

Mod Pathol 2001;14(2):47-53

Copyright $\odot 2001$ by The United States and Canadian Academy of Pathology, Inc.

VOL. 14, NO. 2, P. 47, 2001 Printed in the U.S.A.

Date of acceptance: October 9, 2000.

Address reprint requests to: J. Müller-Höcker, M.D., Pathologisches Institut der Universität München, Thalkirchnerstraße 36, 80337 München, Germany; fax: 089/5160-4043.
Solid pseudopapillary tumor is an uncommon neoplasm of the pancreas accounting for approximately 1 to $2 \%$ of all exocrine tumors of the pancreas (1). It occurs predominantly in girls (not before the age of $9 \mathrm{yr}$ ) and in younger women (mean age, 35 yr). Follow-up has shown that most tumors are clinically indolent. After complete tumor resection, more than $95 \%$ of the patients are cured (1). In malignant behavior, metastases occur most often in the liver (2-7). Only a few patients have died of metastatic disease (reviewed in Solcia et al. (1)). The histogenesis and etiology of the tumor is still unknown. Analysis of ultrastructural studies performed in other investigations favors an origin from a totipotential stem cell with the capacity for endocrine-exocrine differentiation (8-11). An occasional tumor may even be indistinguishable from mitochondria-rich oncocytic carcinoma (12).

In tumor genesis, the study of regulatory, cell cycleassociated cyclins, of cyclin-dependent kinase inhibitors p21, p27, of p53, and others are of special interest in various neoplasms. The cyclins D1 and D3 are important for the transition of cells from the $\mathrm{G} 0 / 1$ phase to the S phase $(13,14)$, and they activate cycledependent kinases. The complex of cyclin D1 and its cycle-dependent kinases phosphorylate retinoblastoma protein and thereby dissociate E2F-1 in its unbound active form (15). E2F-1, a member of the E2F transcription factor family, is the ultimate mediator of G1/S progression (16). E2F-1 may also be directly activated by the $m d m 2$ oncoprotein (17), which additionally has an inhibitory effect on tumor suppressor gene $p 53$ on $\mathrm{Gl}$ transition $(18,19)$.

Dysregulation or activation of D cyclins is documented in a wide variety of human malignancies. Cyclin D1 has especially been shown to be overexpressed in mantle cell lymphomas $(20,21)$ and a variety of carcinomas (22-31). To date, accumulation of cyclin D3 has been studied less often; its accumulation has also been shown to be associated with an increase in breast tumors and pulmonary carcinomas (32, 33).

The cyclin-dependent kinase inhibitors p21 and p27 are reversible inhibitors of cell cycle progression at the G1 and G2 checkpoints (34-40). Along 
with p57/kip2, they interfere with kinase activities of cyclin-cycle-dependent kinases complexes. Functional p21 is essential for p53-mediated G1 arrest (36).

A marked decrease of p27 has been found in endocrine and nonendocrine tumors (37). An inverse correlation between p27 expression and cell proliferation was demonstrated in both normal and neoplastic human tissue; p27 expression was increased in quiescent cells and was expressed to a lesser degree in proliferative cells. In addition, mutations of the $p 53$ suppressor gene have been established in various types of cancers (41).

In the present study, we analyzed the role of these cell cycle-regulatory proteins in two primary solid pseudopapillary tumors of the pancreas and in liver metastases to analyze their role in tumor initiation and progression.

\section{CASE REPORT}

Patient A, a 54-year-old woman, was healthy until nonspecific complaints led to the localization of a circumscribed, nodular, cystic mass in the head of the pancreas by means of nuclear magnetic resonance imaging. Clinical chemistry revealed normal values of GTP (12 U/L). $\gamma$-GT was slightly elevated (19 U/L), as was C-reactive protein $(1.6 \mathrm{mg} / \mathrm{dL})$ and blood glucose $(127 \mathrm{mg} / \mathrm{dL})$. Normal serum levels were obtained for CEA $(<1.0 \mathrm{ng} / \mathrm{mL})$, Ca $72-4(1.7$ $\mathrm{U} / \mathrm{mL}$ ), and Ca 19-9 (7.8 U/mL). Red blood cell counts were $4.6210^{6} / \mu \mathrm{L}$, white blood cell counts were $7500 / \mu \mathrm{L}$, and platelets were $435,000 / \mu \mathrm{L}$. A gastro-pancreatico-duodenectomy (Whipple resection) was performed. The postoperative course and 1 year of follow-up were uneventful.

Patient B, a 12-year-old girl, was found via ultrasonography and magnetic resonance imaging to have a well-circumscribed mass in the tail of the pancreas; she underwent tests because she had accident-related epigastrial pain. A left hemipancreatectomy and splenectomy were performed. The postoperative course was uneventful. The girl developed normally. Normal levels were obtained for red and white blood cells $\left(7000 / \mu \mathrm{L}\right.$ and $4.4410^{6} / \mu \mathrm{L}$, respectively) and platelets $(495,000 / \mu \mathrm{L})$. Liver enzymes ( $\gamma$-GT and GPT) were in the normal range ( 7 and $14 \mathrm{U} / \mathrm{L}$, respectively), as was blood glucose (72 $\mathrm{mg} / \mathrm{dL}$ ) during the next few years.

At the age of 22.5 years, the patient complained of unexplained fatigue. Laboratory investigations of samples found them to be within normal ranges. However, magnetic resonance imaging and ultrasonography revealed six nodular masses (up to 4 $\mathrm{cm}$ ) in both hepatic lobes. A diagnostic liver biopsy and resection of the tumor masses were performed.

\section{MATERIAL AND METHODS}

Formalin-fixed, paraffin-embedded tissue was studied in routine diagnostics (hematoxylin and eosin, EVG, and periodic acid-Schiff). Immunohistochemistry was performed for the detection of epithelial and endocrine differentiation as well as for vimentin and $\alpha 1$-antitrypsin. Furthermore, cell cycle-associated proteins cyclin D1 and cyclin D3, and cell cycle inhibitors (cyclin-dependent kinase inhibitors) p21, p27, and bcl2, mdm2, p53, Ki67 and HER-2/neu were studied immunohistochemically with varying detection methods and antigen retrieval (Table 1). For evaluation of the immunocytochemical results, the amount of reactive cells and the intensity of the reaction (weak, moderate, and strong) were taken into account.

\section{RESULTS}

\section{Gross Findings}

In both patients, a well-circumscribed, partially solid, cystic mass with a gray, focally hemorrhagic

\section{TABLE 1. List of Antisera}

\begin{tabular}{llll}
\hline \multicolumn{1}{c}{ Antiserum } & Origin & Dilution & Method \\
\hline bcl2 & Dako & $1: 20$ & ABC-Elite \\
cerbB-2 (HER-2/neu) & Dako & $1: 1000$ & LSAB \\
MIB-1 (Ki67) & Dianova & $1: 50$ & APAAP \\
ER & Immunotec & $1: 50$ & LSAB \\
PR & Immunotec & $1: 60$ & LSAB \\
p21 & Calbiochem & $1: 100$ & LSAB \\
p27 & Santa Cruz & $1: 100$ & Envision AP \\
Cyclin D1 & Zymed & $1: 100$ & LSAB \\
Cyclin D3 & Dako & ABC-Elite \\
mdm2 & Calbiochem & $1: 300$ & LSAB \\
p53 & Dako & $1: 10$ & LSAB \\
Keratin & BMA & & APAAP \\
Vimentin & Dako & $1: 200$ & APAAP \\
Neuron-specific enolase & Dako & $1: 50$ & $2 \times 7.5$ min, MW, citrate buffer \\
Chromogranin & Dako citrate buffer & $3 \times 10$ min, MW, Protex II \\
Synaptophysin & Dako & $1: 50$ & APAAP \\
\hline
\end{tabular}

ABC, avidin-biotin complex; APAAP, alkaline phophatase-antialkaline phosphatase; ER, estrogen receptor; LSAB, labeled streptavidin-biotin; MW, microwave; PR, progesteron receptor; TRS, target retrieval solution. 

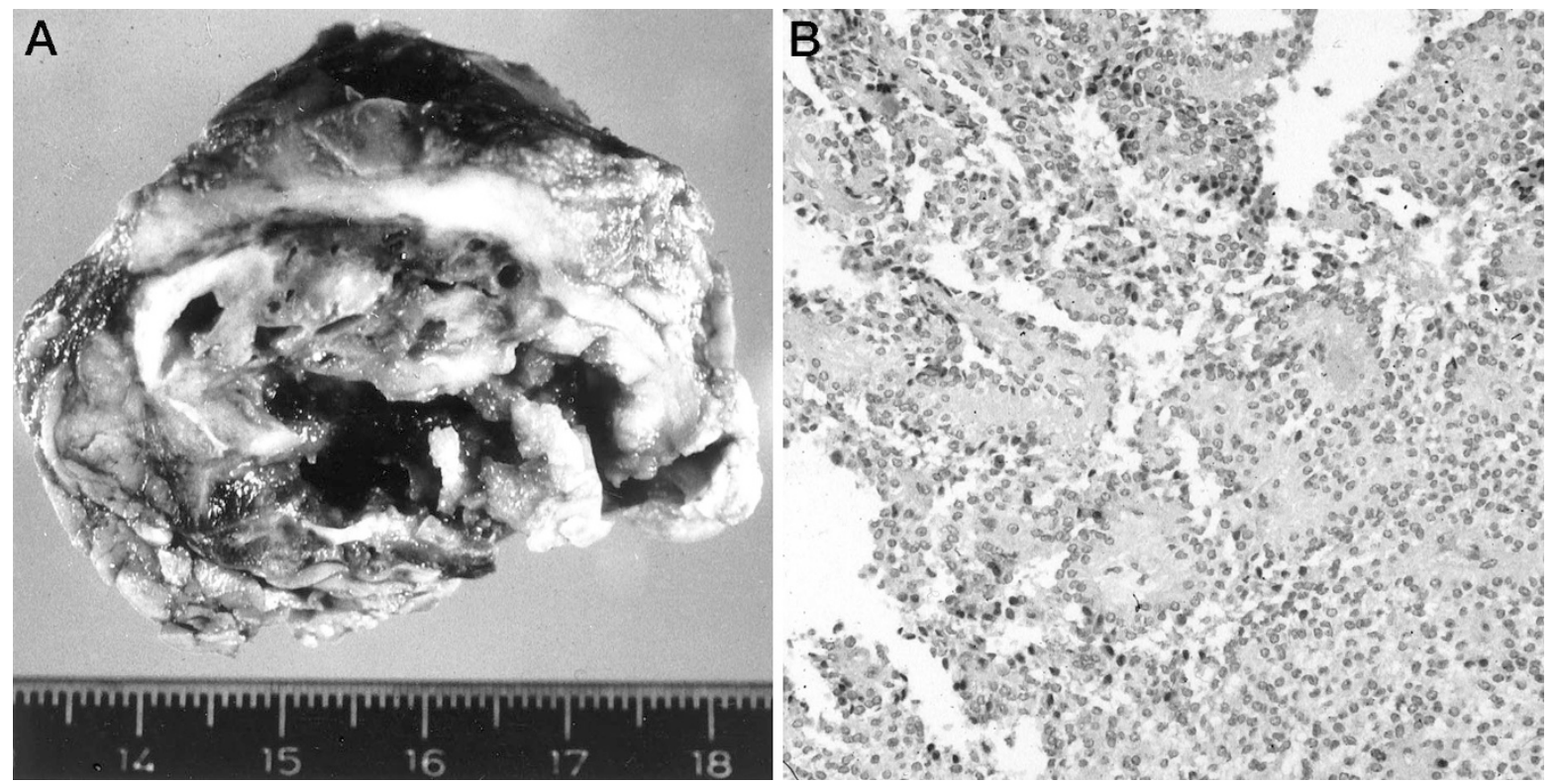

FIGURE 1. A, gross pathomorphology of solid pseudopapillary tumor of the pancreas showing the typical inhomogeneous solid and cystic appearance. B, routine histology. A monomorphous cell population is seen forming solid and pseudopapillary patterns. Hematoxylin and eosin; original magnification, $300 \times$.

cut surface was resected from the pancreas. The diameter was $5 \mathrm{~cm}$ in Patient $A$ and $7.5 \mathrm{~cm}$ in Patient B. On the cut surface, a fibrous pseudocapsule existed that allowed demarcation from the surrounding tissue (Fig. 1A).

\section{Microscopic Findings}

Histology revealed a monomorphous epithelial differentiation of the tumor cells forming solid and pseudopapillary areas with a fibrovascular stalk (Fig. 1B). The cells showed round, nonhyperchromatic nuclei with finely dispersed chromatin and a weakly eosinophilic or clear cytoplasm. Mitosis was not seen. In the cystic areas, hemorrhage and cholesterol clefts, as well as resorptive giant cells, were present. Occasionally islets and ductal structures were included between the tumor tissue. A fibrous capsule separated the tumor tissue from the neighboring regular pancreatic parenchyma, especially at the periphery. In Patient B, the fibrous capsule was invaded by tumor tissue, but an infiltration of the fibrofatty peripancreatic tissue was not seen. The liver metastases had a histologic architecture identical to the primary tumor, with a solid tumor growth pattern and a well-developed fibrovascular stroma.

\section{Immunohistochemistry}

A panel of antibodies was used (Tables 1 and 2). In both tumors, a homogeneous intensive reaction for vimentin, neuron-specific enolase, and a focal intensive reaction for $\alpha 1$-antitrypsin was found. In Patient A, progesterone receptor protein could be localized in the nuclei in more than $50 \%$ of tumor cells with moderate staining intensity. In both patients, estrogen receptor protein was not demonstrated.

Ki67 could not be demonstrated in Patient A and was present in less than $1 \%$ of tumor cells in Patient $B$ in both the primary tumor and the metastasis. Cyclin D1 was expressed in about $50 \%$ of tumor cell nuclei of both tumors (Fig. 2A), with reaction intensity found to be strong in Patient A and moderate in Patient B. In the adjacent regular pancreatic parenchyma, scattered nuclei were also present, but weakly stained. Cyclin D3 was expressed to a lesser degree in both tumors, being present in about $30 \%$ of tumor cell nuclei in Patient A with moderate

TABLE 2. Immunohistochemistry of Cell Cycle Regulatory Proteins in Solid Pseudopapillary Tumor of the Pancreas ${ }^{a}$

\begin{tabular}{|c|c|c|c|c|c|c|c|}
\hline Variable & Cyclin D1 & Cyclin D3 & $\mathrm{p} 21$ & $\mathrm{p} 27$ & p53 & mdm2 & MIB-1 \\
\hline \multirow[t]{2}{*}{ Patient A } & $50 \%$ & $30 \%$ & $100 \%$ & $50-80 \%$ & - & $50 \%$ & - \\
\hline & +++ & ++ & +++ & ++ & & ++ & - \\
\hline \multirow[t]{2}{*}{ Patient B primary tumor } & $50 \%$ & $<5 \%$ & $10 \%$ & $50-100 \%$ & - & $10 \%$ & $<1 \%$ \\
\hline & ++ & ++ & +++ & ++ & & ++ & \\
\hline \multirow[t]{2}{*}{ Metastasis } & $30 \%$ & $<5 \%$ & $10 \%$ & $30 \%$ & - & $<5 \%$ & $<1 \%$ \\
\hline & ++ & ++ & ++ & ++ & & ++ & ++ \\
\hline
\end{tabular}

${ }^{a}$ Staining intensity is as follows: ++ , moderate; +++ , strong. 


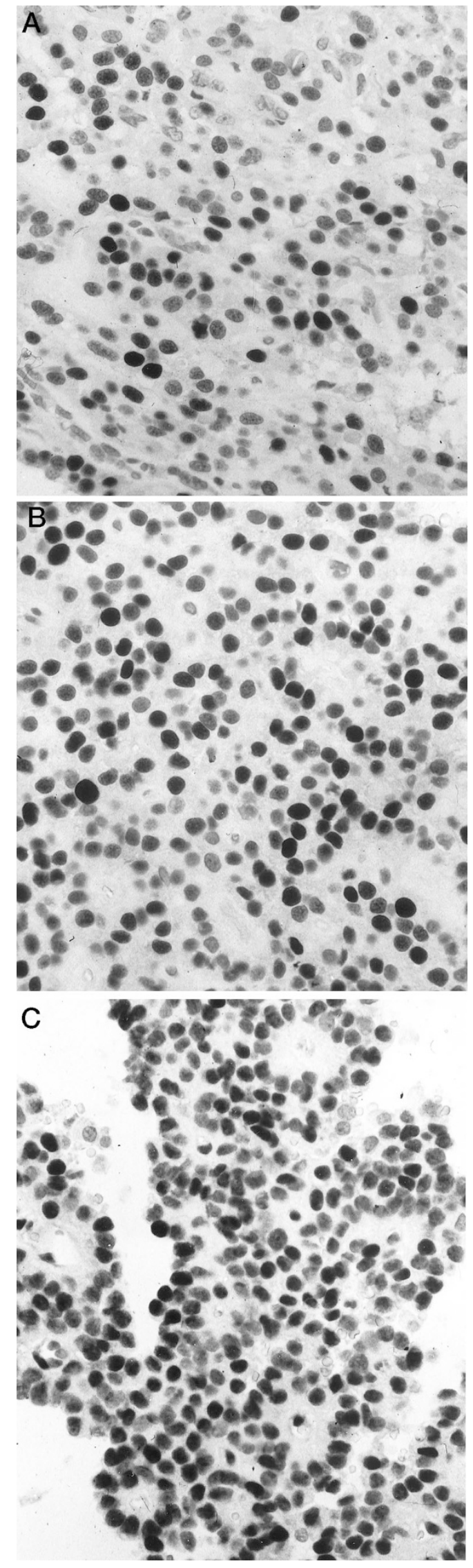

FIGURE 2. A, cyclin D1 expression in about $50 \%$ of tumor cells (Patient A). B, expression of p21 in about $100 \%$ of tumor cells (Patient A). C, expression of p27 protein in about $100 \%$ of tumor cell nuclei (Patient B, primary tumor). Original magnification, $480 \times$. reaction intensity, whereas in Patient $\mathrm{B}$, less than $5 \%$ of cells reacted positively. The exocrine pancreas remained unstained, and islet cells showed a regular and intensive staining.

p21 protein was intensively expressed in nearly $100 \%$ of tumor cell nuclei in Patient A (Fig. 2B) and about in $10 \%$ of tumor cell nuclei of Patient B. In normal exocrine parenchyma, less than $1 \%$ of cell nuclei were moderately stained. p27 showed a moderate staining intensity in 50 to $100 \%$ of cells with an inhomogeneous reaction pattern in both tumors (Fig. 2C). The immunoreactivity for cyclin D3 and p21 in tumor tissue in the liver was at a similarly low level as in the primary tumor, whereas a slightly lower immunoreactivity was found for p27 and cyclin D1 (Fig. 3). No expression of p53 protein could be detected in the primary tumors and in the metastatic tumor tissue.

Negative immunohistochemical staining reactions were obtained in both patients for bcl2, HER$2 /$ neu, chromogranin, and synaptophysin, as well as for keratin in Patient A; Patient B showed focal reactivity for keratin in about $30 \%$ of tumor cells.

\section{DISCUSSION}

The solid pseudopapillary tumor of the pancreas is still an enigma (42); it is a rare tumor of uncertain histogenesis and undetermined differentiation (8) and with low malignant potential. The tumor is likely derived from a pluripotent indifferent stem cell capable of both endocrine and exocrine differentiation.

A recent review reports 174 cases in the literature (7). Twenty-two of these patients' tumors had metastasized (7). Metastases most often occurred in the liver (15 of 22 patients). Multiple metastases, as in the patient we studied, are not uncommon (2-5, $10,43)$. As in the patient we studied, patients younger than 20 years of age at tumor diagnosis may have metastatic disease 8 to 10 years later (7), whereas patients diagnosed when they are older experience a shorter tumor-free interval. The morphology of the metastases in most cases does not differ from that of the primary tumor, as shown in the patient we studied. Both the primary tumor and the liver metastases had an extremely low staining for MIB-1 in our study. In one patient with peritoneal spread, a high mitotic index has been described (2). Death as a result of tumor metastases has been reported in four patients (7) 4 to 11 years after diagnosis. In two of these patients, aged 47 and 60 years, the tumor had been undiagnosed for 9 and 25 years, respectively (2).

Surgical resection in most cases has proven to be sufficient for cure. Tamoxifen therapy was administered to two patients who experienced metasta- 


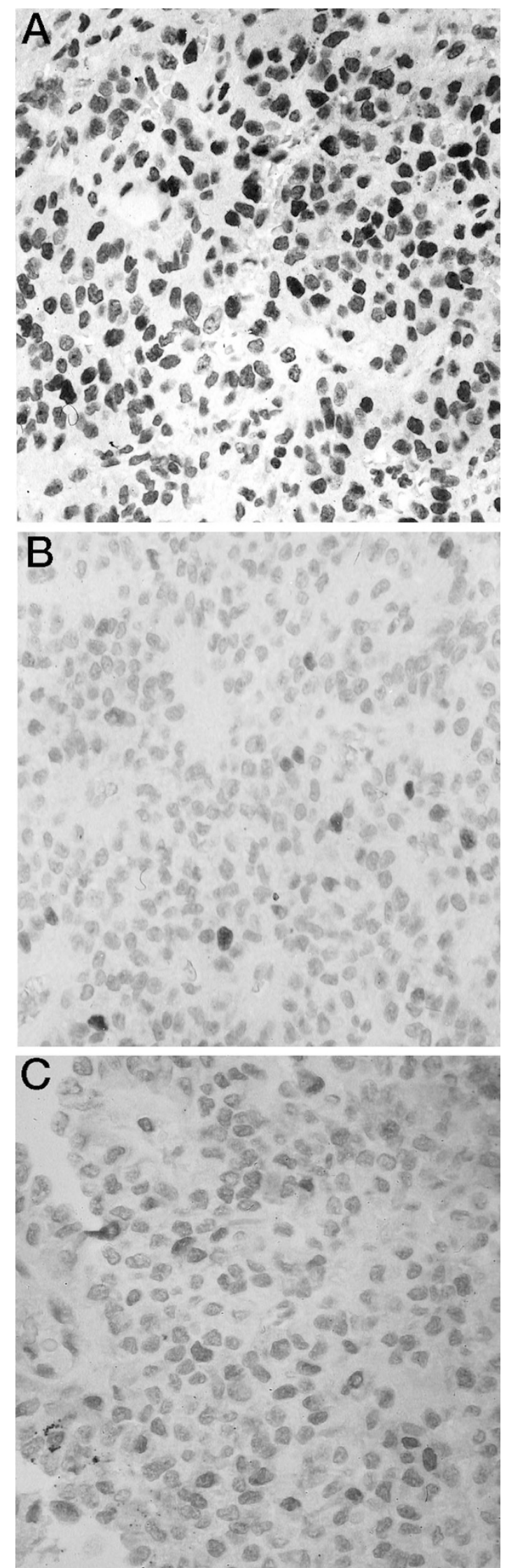

FIGURE 3. Liver metastasis. A, moderate expression of cyclin D1 in about $30 \%$ of tumor cell nuclei. B, low-level of expression of p21 protein, similar to that of the primary tumor. $\mathbf{C}$, moderate expression of p27 in about $30 \%$ of tumor cells, reduced in comparison to the primary tumor (see Fig. 2C). Original magnification, $480 \times$. ses. The success of this type of treatment has not been documented, however (5). In one patient with multiple metastases of the liver, chemoembolization proved useful as a palliative measure for tumor regression (43). Liver metastases developed in one patient despite gamma irradiation and chemotherapy of the primary tumor (2).

The criteria determining malignant behavior of solid pseudopapillary tumor of the pancreas are still difficult to define. Mitotic activity, perineural angioinvasion, and infiltration of peripancreatic tissue have been proposed as discriminating factors (1). In one study (3), venous invasion, a higher nuclear grade, and prominent necrobiotic changes were associated with hepatic, peritoneal, and nodal metastasis (3). However, only three cases could be analyzed.

Flow cytometric analyses have shown that most tumors are diploid $(3,8,44)$, although focal aneuploidy may be found after extensive sampling (44). Two tumors with metastatic disease were DNA aneuploid $(3,4)$. However, the small number of patients does not allow a definitive conclusion on the prognostic validity of DNA cytometry.

To our knowledge, the present study reports for the first time on the expression of cell cycle proteins in two cases of solid pseudopapillary tumor of the pancreas. Our study emphasizes that solid pseudopapillary tumors are extremely low proliferative neoplasms that lack evidence for dysregulation of the $p 53$ gene. Instead, there was evidence of dysregulation of activating cyclins and inhibitory proteins, although to a varying extent in both patients.

We found an increased protein expression of cyclin D1 and of p21 and p27 protein. Interestingly, p21 was highly expressed in nearly $100 \%$ of tumor cells in one of the two patients. However, in the patient with liver metastasis, p21 expression was found only in about $10 \%$ of cells both in the primary tumor and in the liver metastases. Cyclin D1 was expressed at similar rates in both primary tumors, and the expression of cyclin D1 was not enhanced in the metastatic liver tissue. D cyclins are deregulated in a wide range of human malignancies. Cyclin D1 in particular has been shown to be overexpressed in mantle cell lymphoma and in a variety of carcinomas (19-31). In transitional carcinoma of the bladder (27) and ductal carcinoma in situ of the breast (45), cyclin D1 expression correlates inversely with the degree of differentiation.

Accumulation of p21 has been found to correlate with increased rate of proliferation and aggressive clinical course-for example, in head and neck squamous carcinoma (46) or in multiple myeloma (47) - indicating that the antiproliferative effect of p21 on the cell cycle progression may be overridden by other mechanisms. However, in low-malignancy solid pseudopapillary tumor of the pancreas, p21 
and p27 cyclin-dependent kinase inhibitor upregulation appears to continue to function, as judged from the extremely low pool of Ki67-positive cells in both the primary tumor and the liver metastases.

How p27 protein accumulates in solid pseudopapillary tumor remains to be clarified. It is known that p21 accumulation may occur through a p53independent mechanism (48), which would seem to be the case in the patients we report. In vitro studies have shown that cyclin D1 induces transcriptional activation of p21 (49). It may therefore be assumed that in the case of solid pseudopapillary tumor, overexpression of cyclin D1 may be involved in the overexpression of p21. Although p21 protein was expressed to a lesser degree in Patient B than in Patient A, and although p27 protein was somewhat reduced in the metastatic tumor tissue of patient B compared with the primary tumor, our results give no definitive explanation for the metastatic potential of this tumor.

In summary, there is evidence of deregulation of cell cycle proteins in solid pseudopapillary tumor of the pancreas with varying overexpression of cell cycle-activating and cell cycle-inhibiting proteins. These features may help to explain the generally good clinical outcome of these rare tumors. However, it remains to be clarified how these alterations are involved in the initiation and progression of this type of tumor. The lack of expression of c-erbB-2 (HER-2/neu) and of p53 emphasizes that the pathogenesis of solid pseudopapillary tumor differs from that of usual carcinoma of the pancreas $(50,51,52)$. However, the role of cyclins and cyclin-dependent kinase inhibitors has not yet been fully investigated in pancreatic adenocarcinoma $(53,54)$. At least it is known that inactivation of the p16 pathway may occur $(53,54)$ and that loss of p27 is associated with a poor prognosis (55).

Acknowledgments: The authors are indebted to S. Nikolarakis and M. Wittmaier for their careful preparation of the manuscript and to Prof. W. Nathrath, Institute of Pathology, Städt, Krankenhaus Hanlaching, for providing tissue from the primary tumor of Patient B.

\section{REFERENCES}

1. Solcia E, Capella C, Klöppel G. Tumors of the pancreas. AFIP Third Series 1997;20:120-9.

2. Matsunou H, Konishi F. Papillary-cystic neoplasm of the pancreas: a clinicopathologic study concerning the tumor aging and malignancy of nine cases. Cancer 1990;65:283-91.

3. Nishihara K, Nagoshi M, Tsuneyoshi M, Yamaguchi K, Hayashi I. Papillary cystic tumors of the pancreas. Assessment of their malignant potential. Cancer 1993;71:82-92.

4. Cappellari JO, Geisinger KR, Albertson DA, Wolfman NT, Kule TE. Malignant papillary cystic tumor of the pancreas. Cancer 1990;66:193-8.
5. Sclafani LM, Reuter VE, Coit DG, Breman MF. The malignant nature of papillary and cystic neoplasm of the pancreas. Cancer 1991;68:153-8.

6. Zinner MJ, Shurbaji MS, Cameron JL. Solid and papillary epithelial neoplasms of the pancreas. Surgery 1990;108:47580.

7. Horisawa M, Niinomi N, Sato T, Yokoi S, Oda K, Ichikawa M. Frantz's tumor (solid and cystic tumor of the pancreas) with liver metastasis: successful treatment and long-term followup. J Pediatr Surg 1995;30:724-6.

8. Pettinato G, Manivel JC, Ravetto C, Terracciano LM, Gould EW, di-Tuoro A, et al. Papillary cystic tumor of the pancreas. A clinicopathologic study of 20 cases with cytologic, immunohistochemical, ultrastructural, and flow cytometric observations, and a review of the literature. Am J Clin Pathol 1992;98:478-88.

9. Balercia G, Zamboni G, Bogina G, Mariuzzi GM. Solid-cystic tumor of the pancreas. An extensive ultrastructural study of fourteen cases. J Submicrosc Cytol Pathol 1995;27:331-40.

10. Stömmer P, Kraus J, Stolte M, Giedl J. Solid and cystic pancreatic tumors. Clinical, histochemical, and electron microscopic features in ten cases. Cancer 1991;67:1635-41.

11. Miettinen M, Partanen S, Fräki O, Kivilaakso E. Papillary cystic tumor of the pancreas. An analysis of cellular differentiation by electron microscopy and immunohistochemistry. Am J Surg Pathol 1987;11:855-65.

12. Lee WY, Tzeng CC, Jin YT, Chow NH, Yip CM, Lee JC. Papillary cystic tumor of the pancreas: a case indistinguishable from oncocytic carcinoma. Pancreas 1993;8:127-32.

13. Pines J. Cyclins and cyclin-dependent kinases: a biochemical view. Biochem J 1995;308:697-711.

14. Dirks PB, Rutka JT. Current concepts in neuro-oncology: the cell cycle-a review. Neurosurgery 1997;40:1000-15.

15. Helin K, Harlow E. The retinoblastoma protein as a transcriptional repressor. Trends Cell Biol 1993;3:43-6.

16. Slansky JE, Farnham PJ. Introduction to the E2F family: protein structure and gene regulation. In: Farnham PJ, editor. Current topics in microbiology and immunology. Transcriptional control of cell growth: the E2F family. Vol 208. Berlin: Springer-Verlag; 1996. p. 1-30.

17. Martin K, Trouche D, Hagemeier C, Sorensen TS, La Thangue NB, Kouza Kouzarides T. Stimulation of E2F1/DP1 transcriptional activity by MDM2 oncoprotein. Nature 1995; 375:691-4.

18. Finlay CA. The $m d m-2$ oncogene can overcome wild-type p53 suppression of transformed cell growth. Mol Cell Biol 1993;13:301-6.

19. Hall M, Peter G. Genetic alterations of cyclins, cyclindependent kinases, and cdk inhibitors in human cancer. Adv Cancer Res 1996;68:67-108.

20. Rimokh R, Berger F, Delsol G, Chanin C, Bertheas MF, Ffrench $\mathrm{M}$, et al. Rearrangement and overexpression of the bcl-1/PRAD-1 gene in intermediate lymphocytic lymphomas and in t(11q13)-bearing leukemias. Blood 1993;81:3063-7.

21. Vasef MA, Medeiros LJ, Koo C, McCourty A, Brynes RK. Cyclin D1 immunohistochemical staining is useful in distinguishing mantle cell lymphoma from other low-grade B-cell neoplasms in the bone marrow. Am J Clin Pathol 1997;108: 302-7.

22. Barnes DM. Cyclin D1 in mammary carcinoma. J Pathol 1997;181:267-9.

23. Michalides R, van Veelen N, Hart A, Loftus B, Wientjens E, Balm A. Overexpression of cyclin D1 correlates with recurrence in a group of 47 operable squamous cell carcinomas of the head and neck. Cancer Res 1995;55:975-8.

24. Sheyn I, Noffsinger AE, Heffelfinger S, Davis B, Miller MA, Fenoglio-Preiser CM. Amplification and expression of the cyclin D1 gene in anal and esophageal squamous cell carcinomas. Hum Pathol 1997;28:270-6. 
25. Jares P, Fernandez PL, Campo E, Nadal A, Bosch F, Aiza G. PRAD-1/cyclin D1 gene amplification correlates with messenger RNA overexpression and tumor progression in human laryngeal carcinomas. Cancer Res 1994;54:4813-7.

26. Bringuier PP, Tamini Y, Schuuring E, Schalken J. Expression of cyclin D1 and EMS1 in bladder tumours: relationship with chromosome 11q13 amplification. Oncogene 1996;12:174753.

27. Lee CCR, Yamamoto S, Morimura K, Wanibuchi H, Nishisaka N, Ikemoto S. Significance of cyclin D1 overexpression in transitional cell carcinomas of the urinary bladder and its correlations with histopathologic features. Cancer 1996;79: 780-9.

28. Lin BTY, Brynes RK, Gelb AB, McCourty A, Amin MB, Medeiros LJ. Cyclin D1 expression in renal carcinomas and oncocytomas: an immunohistochemical study. Mod Pathol 1998;11:1075-81.

29. Bartkova J, Lukas J, Müller H, Strauss M, Gusterson B, Bartek J. Abnormal patterns of D-type cyclin expression and G1 regulation in human head and neck cancer. Cancer Res 1995;55:949-56.

30. Bartkova J, Lukas J, Strauss M, Bertek J. Cyclin D1 oncoprotein aberrantly accumulates in malignancies of diverse histogenesis. Oncogene 1995;10:775-8.

31. Hung WC, Chai CY, Huang JS, Chuang LY. Expression of cyclin D1 and c-Ki-ras gene product in human epithelial ovarian tumors. Hum Pathol 1996;27:1324-8.

32. Bartkova J, Zemanova M, Bartek A. Abundance and subcellular localisation of cyclin D 3 in human tumours. Int J Cancer 1996;65:323-7.

33. Usuda H, Saito T, Emura I, Naito M. Immunohistochemistry of cyclin D3 in pulmonary carcinomas. Virchows Arch 1996; 428:159-63.

34. Toyoshima H, Hunter T. p27, a novel inhibitor of G1 cyclin/ cdk protein kinase activity, is related to p21. Cell 1994;78:6774 .

35. Xiong Y, Hannon GT, Zhang H, Casso D, Kobayashi R, Beach D. p21, a universal inhibitor of cyclin kinase. Nature 1993; 366:701-4.

36. Waldman T, Kinzler KW, Vogelstein B. p21 is necessary for the p53-mediated $G_{1}$ arrest in human cancer cells. Cancer Res 1995;55:5187-90.

37. Lloyd RV, Jin L, Qian X, Kulig E. Aberrant expression p27 ${ }^{\text {kip1 }}$ in endocrine and other tumors. Am Pathol 1997;150:401-7.

38. Coats S, Flanagan W, Nourse J, Roberts J. Requirement of p2 $7^{\text {kip } 1}$ for restriction point control of the fibroblast cell cycle. Science 1996;272:877-80.

39. Nourse J, Firpo E, Flanagan M, Coats S, Polyak C, Lee M. Interleukin-2 mediates elimination of p27/kip1 cyclindependent kinase inhibitor prevented by rapamycin. Nature 1994;372:570-3.

40. Hengst L, Reed S. Translation control of p27/kip1 accumulation during the cell cycle. Science 1996;271:1861-4.
41. Hollstein M, Sidransky D, Vogelstein B, Harris CC. p53 mutations in human cancer. Science 1991;253:49-53.

42. Mendelsohn G. Papillary cystic tumor of the pancreas: an enigma. Am J Clin Pathol 1992;98:476-7.

43. Matsuda Y, Imai Y, Kawata S, Nishikawa M, Miyoshi S, Saito R. Papillary cystic neoplasm of the pancreas with multiple hepatic metastases: a case report. Gastroenterol Jpn 1987;22: 379-84.

44. Wilson MB, Adams DB, Garen PD, Gansler TS. Aspiration cytologic, ultrastructural, and DNA cytometric findings of solid and papillary tumor of the pancreas. Cancer 1992;69: 2235-43.

45. Simpson JF, Quan DE, O'Malley F, Odum-Maryon T, Clark PE. Amplification of CCND-1 and expression of its protein product, cyclin D1, in ductal carcinoma in situ of the breast. Am J Pathol 1997;151:161-8.

46. Erber R, Klein W, Andl T, Enders C, Born AI, Conradt C. Aberrant p21 (CIP1/WAF1) protein accumulation in head and neck cancer. Int J Cancer 1997;73:383-9.

47. Lai R, Medeiros LJ, Wilson CS, Sun NC, Koo C, McCourty A. Expression of the cell-cycle-related E2F 1, p53, mdm-2, p21 $1^{\text {waf- }}$, and Ki-67 in multiple myeloma: correlation with cyclin-D1 immunoreactivity. Mod Pathol 1998;11:642-647.

48. Akashi M, Hachiya M, Osawa Y, Spirin K, Suzuki G, Koeffler HP. Irradiation induces WAF1 expression through a p53independent pathway in KG-1 cells. J Biol Chem 1995;270: 19181-7.

49. Hiyama H, Iavarone A, LaBaer J, Reeves SA. Regulated ectopic expression of cyclin D1 induces transcriptional activation of the cdk inhibitor $p 21$ gene without altering cell cycle progression. Oncogene 1997;14:2533-42.

50. Berrozpe G, Schaeffer J, Peinado MA, Real FX, Perucho M. Comparative analysis of mutations in the $p 53$ and $K$-ras genes in pancreatic cancer. Int J Cancer 1994;58:185-91.

51. Day JD, Digiuseppe JA, Yeo C, Lai-Goldman M, Anderson SM, Goodman SN. Immunohistochemical evaluation of HER-2/neu expression in pancreatic adenocarcinoma and pancreatic intraepithelial neoplasms. Hum Pathol 1996;27: $119-24$.

52. Apple SK, Hecht JR, Lewin DN, Jahromi SA, Grady WW, Nieberg RK. Immunohistochemical evaluation of K-ras, p53, and HER-2/neu expression in hyperplastic, dysplastic, and carcinomatous lesions of the pancreas: evidence for multistep carcinogenesis. Hum Pathol 1999;30:123-9.

53. Chu TM. Molecular diagnosis of pancreas carcinoma. J Clin Lab Anal 1997;11:225-31.

54. Goggins M, Kern SE, Offerhaus JA, Hruban RH. Progress in cancer genetics: lesson from pancreatic cancer. Ann Oncol 1999;10(Suppl 4):4-8.

55. Lu CD, Morita S, Ishibashi $\mathrm{T}$, Hara H, Isozaki H, Tanigawa W. Loss of p27Kip1 expression independently predicts poor prognosis for patients with resectable pancreatic adenocarcinoma. Cancer 1999;85:1250-60. 